\title{
SPECIES DIFFERENTIATION IN THE GENUS LOLIUM
}

\author{
BERYL NAYLOR \\ Agricultural Research Council Unit of Biometrical Genetics, \\ Department of Genetics, University of Birmingham
}

Received 9.v.60

\section{INTRODUCTION}

THE genus Lolium consists of many morphologically distinct forms which, while their relationships have not been clearly elucidated, are generally regarded as distinct species. Despite this, L. italicum was first regarded as the variety multiflorum of $L$. perenne (Jenkin, I93I) before being raised to specific rank by Braun. Jenkin $(1954 b, c)$ while still maintaining that "... at no point have results been obtained which are essentially different from those obtainable in intra-specific crosses" one year later (1955b) also accepts $L$. italicum as a species. This reversal of opinion depended upon the fact that $L$. perenne and $L$. italicum gave differing results in regard to seed-set and germination when crossed with L. loliaceum.

Clearly this situation is far from satisfactory and for this reason an intensive comparison of the two types and their $F_{1}$ and $F_{2}$ hybrids has been carried out using both nuclear and external morphological characters.

\section{MATERIAL AND METHOD}

Plants from separate Lolium perenne $\left(\mathrm{P}_{1}\right)$ and L. italicum $\left(\mathrm{P}_{2}\right)$ populations were allowed to open pollinate in isolation in 1955 to give seed which was sown in 1957 and 1958 as parental control populations (text-fig.). Reciprocal crosses were made in 1955 and 1956 taking females at random from both $P_{1}$ and $P_{2}$. Some of the seed obtained from the 1955 crosses was sown in 1956 and allowed to open pollinate to give the $\mathbf{F}_{2}$ which was grown in $\mathbf{1 9 5 7}$. These same $\mathbf{F}_{1}$ plants (plate I) were kept as tillers and the reciprocal crosses isolated from one another in 1957. Seed collected from them was then grown as two separate $F_{2}$ populations in 1958 . The remainder of the $F_{1}$ hybrids made in 1955 and 1956 constituted the $1957 F_{1}$.

The characters chosen for scoring may be divided into two groups :

(a) Nuclear characters. Whole heads were fixed and examined cytologically by means of aceto-carmine squashes in respect of :

(i) Chiasma frequency-this was scored in 20 pollen mother cells at MI of meiosis in each plant. The following metrics were derived :

(I) Chiasma frequency-expressed as the average number per bivalent for the 20 cells scored.

(2) Cell variance-the variation, in average chiasma frequency per bivalent, between the 20 cells scored in each plant.

(3) Bivalent variance-the variation in chiasma frequency between the bivalents within the 20 cells scored.

(ii) Structural and meiotic abnormalities-where possible ıo MI and 30 AI cells of each plant were scored for the frequency of abnormal cells. 
(b) External morphological characters. Fully mature plants in the field were scored for the following characters :

(i) Height - the height of the tallest tiller in inches.

(ii) Tiller number - the total number of flowering tillers per plant.

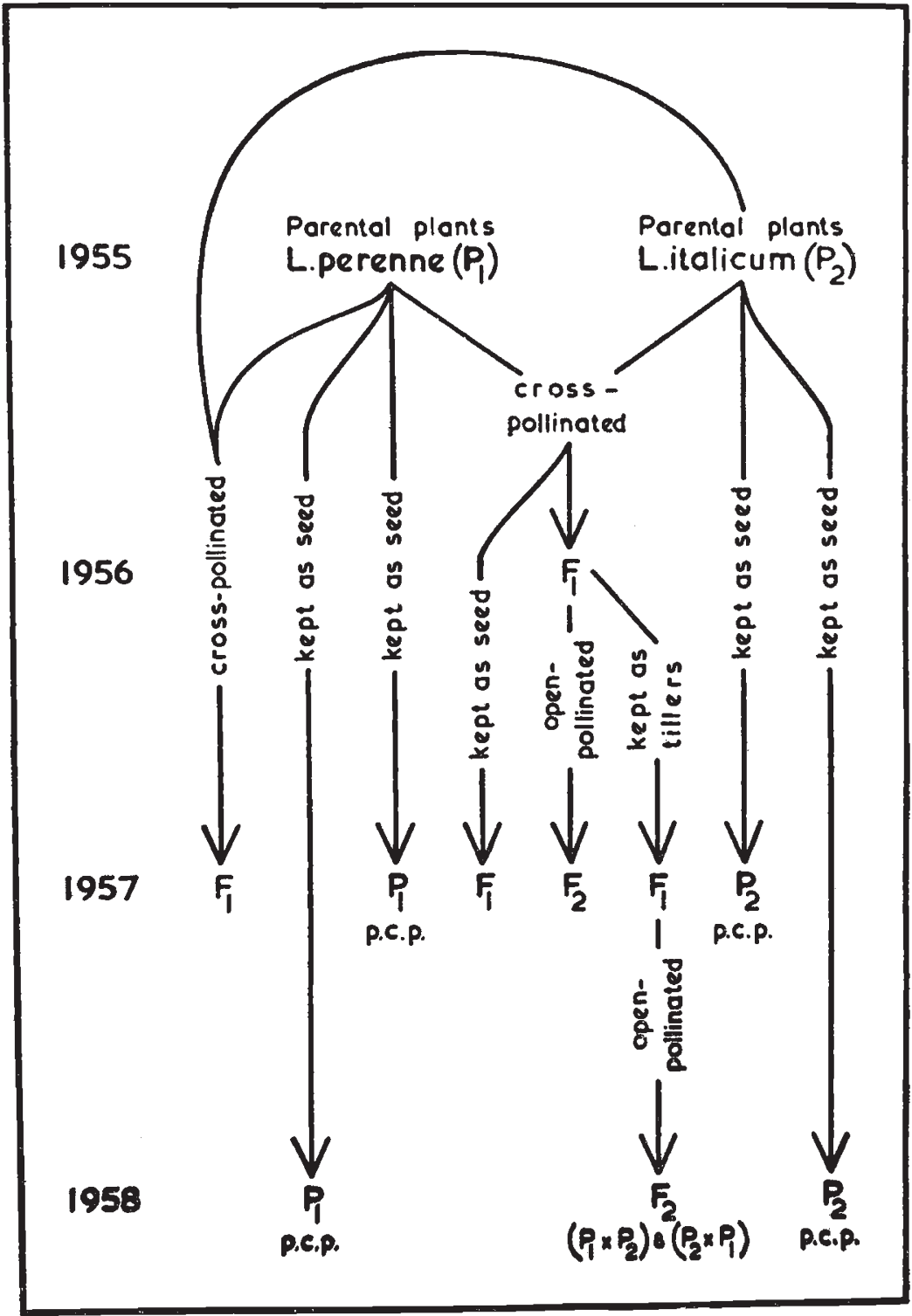

TEXT-FIG.-Progeny chart.

(iii) Spikelet number - the number of spikelets borne on each of the tallest two tillers were counted so that two metrics could be obtained :

(I) Mean spikelet number-i.e. the average number of spikelets on the two tillers.

(2) Spikelet difference-i.e. the difference in numbers of the spikelets borne on the two tillers. 
(iv) Flower number-the number of flowers contained in the fourth lowest spikelet of the tillers scored in (iii) above. Again two metrics were derived :

(I) Mean flower number-the average number of flowers counted on the two spikelets.

(2) Flower difference-the difference in numbers of flowers between the two spikelets.

Variation in all these characters is continuous and presumably under polygenic control (Mather, I94I).

\section{OBSERVATIONS}

(1) The comparison between parental control populations and $F_{1}$ hybrids

The presence of differently balanced polygenic systems may be demonstrated if crossing them results in the production of types with

TABLE I

Plant chiasma frequencies, cell variances and bivalent variances of the parental populations, their hybrids and hybrid derivatives

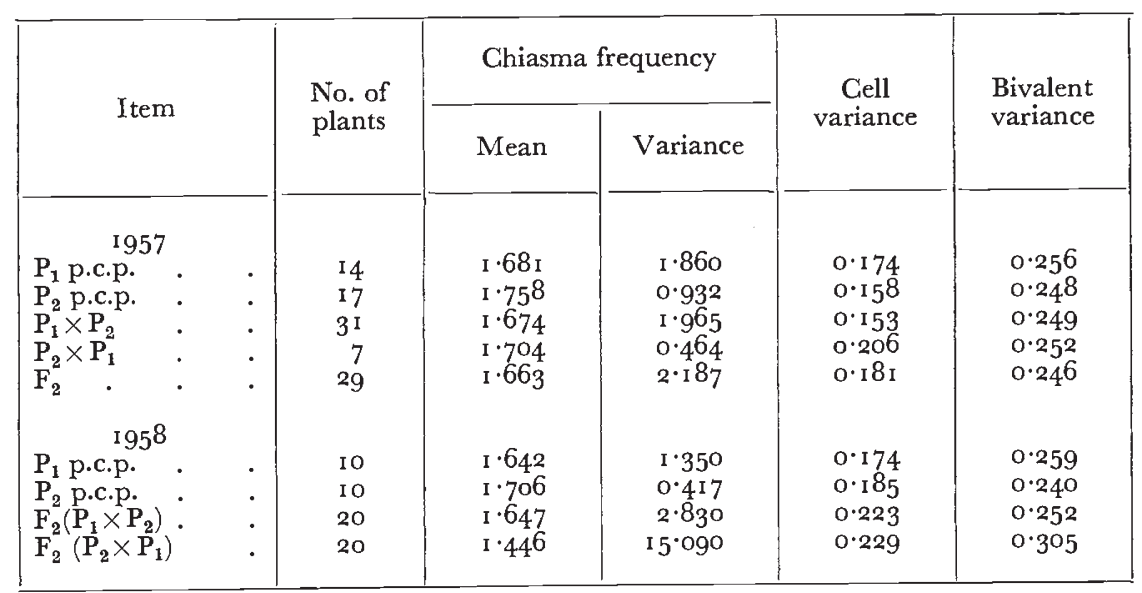

a disturbed balance. Such a disturbance shows itself in the $F_{1}$ either as heterosis, i.e. a difference between the mean of the $F_{1}$ and that of the parents (Mather, I943), or as an increase in the range of phenotypes, which will be reflected in an increased variance of the $F_{1} s$ over the parents. Observations were therefore directed to determine whether such changes occur.

\section{(a) Nuclear characters}

(i) Chiasma frequency. The means and variances for the parental populations and their hybrids are set out in table I. An analysis of variance of the mean chiasma frequency shows no significant difference between the two years for either of the parental populations. The results were therefore pooled over years before making comparisons between the parental populations and $F_{1}$ s. Analysis of the 
pooled data shows that the mean chiasma frequency of the $\mathrm{P}_{1}$ parental populations is significantly less than that of the $\mathrm{P}_{2}$ parental populations (table 2). The mean of the $\mathrm{F}_{\mathbf{1}} \mathrm{s}$ is significantly less than that of the

TABLE 2

Analysis of variance of chiasma frequency in the parental populations and their $F_{1} s$

\begin{tabular}{|c|c|c|c|c|}
\hline Item & $\mathrm{N}$ & MS & VR & $\mathbf{P}$ \\
\hline $\begin{array}{l}\mathrm{P}_{1} \text { p.c.ps. } v \mathrm{P}_{2} \text { p.c.ps } \\
\text { Error } .\end{array}$ & $\begin{array}{r}I \\
49\end{array}$ & $\begin{array}{r}\text { I } 373 \\
\text { I67 }\end{array}$ & $\begin{array}{l}8 \cdot 20 \\
\cdots\end{array}$ & $\begin{array}{c}0 \cdot 0 \mathrm{I}-0 \cdot 00 \mathrm{I} \\
\ldots\end{array}$ \\
\hline $\begin{array}{l}\mathrm{P}_{1} \text { p.c.ps. } v \mathbf{F}_{1} \\
\text { Error } .\end{array}$ & $\begin{array}{r}I \\
60\end{array}$ & $\begin{array}{r}60 \cdot 14 \\
233 \cdot 45\end{array}$ & $\begin{array}{c}<\mathrm{I} \cdot \mathrm{OO} \\
\ldots\end{array}$ & $\begin{array}{c}\text { Not significant } \\
\ldots\end{array}$ \\
\hline $\begin{array}{l}\mathrm{P}_{2} \text { p.c.ps. } v \mathrm{~F}_{1} \\
\text { Error } .\end{array}$ & $\begin{array}{r}1 \\
63\end{array}$ & $\begin{array}{r}1107 \\
186\end{array}$ & $\begin{array}{l}5 \cdot 97 \\
\cdots\end{array}$ & $\begin{array}{c}0.05-0 \cdot 01 \\
\ldots\end{array}$ \\
\hline
\end{tabular}

parental populations with the higher mean $\left(\mathrm{P}_{2}\right)$ but does not differ significantly from that of $\mathrm{P}_{1}$ (table 2 ).

The variances of the distribution of chiasma frequency appear to be related to the size of the mean (see table I). A significant negative

TABLE 3

Frequency of cells showing structural and meiotic abnormalities in the parental control populations, their hybrids and hybrid derivatives

\begin{tabular}{|c|c|c|c|c|c|c|c|c|c|}
\hline \multirow{3}{*}{ Abnormality } & \multicolumn{5}{|c|}{ г 957} & \multicolumn{4}{|c|}{$195^{8}$} \\
\hline & \multicolumn{2}{|c|}{ P.C.P. } & \multicolumn{2}{|c|}{$F_{1}$} & \multirow{2}{*}{$F_{2}$} & \multicolumn{2}{|c|}{ P.C.P. } & \multicolumn{2}{|c|}{$\mathrm{F}_{2}$} \\
\hline & $P_{1}$ & $\mathrm{P}_{2}$ & $\mathrm{P}_{1} \times \mathrm{P}_{2}$ & $\mathrm{P}_{2} \times \mathrm{P}_{1}$ & & $P_{1}$ & $\mathrm{P}_{2}$ & $\mathrm{P}_{1} \times \mathrm{P}_{2}$ & $\mathrm{P}_{2} \times \mathrm{P}_{1}$ \\
\hline $\begin{array}{c}M I \\
\text { Breakage }\end{array}$ & & & 0 & o & & & & & \\
\hline Uncoiling & I/1000 & $0 / 1000$ & $1 / 1500$ & $0 / 500$ & $5 / 2000$ & $0 / 500$ & $0 / 500$ & $\begin{array}{l}4 / 1500 \\
1 / 1500\end{array}$ & $\begin{array}{l}0 / 1500 \\
1 / 1500\end{array}$ \\
\hline $\begin{array}{l}\text { Extra } \\
\text { chromosomes }\end{array}$ & $2 / 1000$ & $0 / 1000$ & $1 / 1500$ & $0 / 500$ & $0 / 2000$ & 0 & 0 & o & 0 \\
\hline Fragments & 0 & 0 & 0 & 0 & 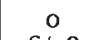 & $0 / 500$ & $0 / 500$ & $6 / 1500$ & $1 / 1500$ \\
\hline Asynapsis & $14 / 280$ & $8 / 34^{\circ}$ & $14 / 620$ & $3 / 14^{0}$ & $26 / 5^{80}$ & $7 / 200$ & $1 / 200$ & $33 / 400$ & $109 / 400$ \\
\hline $\begin{array}{c}A I \\
\text { Bridge and }\end{array}$ & $0 / 300$ & $0 / 300$ & $0 / 45^{\circ}$ & $0 / 150$ & $1 / 600$ & $0 / 150$ & $0 / 150$ & $5 / 45^{\circ}$ & $0 / 450$ \\
\hline $\begin{array}{l}\text { fragments } \\
\text { Extras }\end{array}$ & 0 & 0 & o & 0 & o & $0 / 150$ & $0 / 150$ & $\mathrm{I} / 45^{\circ}$ & $0 / 450$ \\
\hline
\end{tabular}

regression was found $\left(\mathrm{VR}=3 \mathrm{I} \cdot 90\right.$ for $\left.\mathrm{N}_{1}=\mathrm{I}, \mathrm{N}_{2}=7 ; \mathrm{P}<0 \cdot \mathrm{OoI}\right)$, indicating that the size of the variance is negatively correlated with the mean. The residual item in the analysis is not significant therefore 
no further information can be obtained from a consideration of variances.

The results of the variation between pollen mother cells in an individual and between bivalents within these cells are summarised in table I, columns 5 and 6 . Analyses of variance for both metrics show that the $F_{1}$ hybrids do not differ significantly from the two parental populations. This implies that the environmental component of chiasma variation is comparable in all three cases.

TABLE 4

Means and variances of the external morphological characters scored in the parental control populations, their hybrids and hybrid derivatives

\begin{tabular}{|c|c|c|c|c|c|c|c|c|c|c|c|c|c|}
\hline \multirow{3}{*}{ Item } & \multirow{3}{*}{$\begin{array}{c}\text { No. } \\
\text { of } \\
\text { plants }\end{array}$} & \multirow{2}{*}{\multicolumn{2}{|c|}{ Height }} & \multirow{2}{*}{\multicolumn{2}{|c|}{ Tillers }} & \multicolumn{4}{|c|}{ Spikelets } & \multicolumn{4}{|c|}{ Flowers } \\
\hline & & & & & & \multicolumn{2}{|c|}{ Mean no. } & \multicolumn{2}{|c|}{ Difference } & \multicolumn{2}{|c|}{ Mean no. } & \multicolumn{2}{|c|}{ Difference } \\
\hline & & $\bar{x}$ & V & $\tilde{x}$ & V & $\bar{x}$ & V & $\bar{x}$ & V & $\bar{x}$ & V & $\bar{x}$ & V \\
\hline $\begin{array}{r}1957 \\
\end{array}$ & & & & & & & & & & & & & \\
\hline $\begin{array}{l}P_{1} \text { p.c.p. } \\
P_{2} \text { p.c.p. }\end{array}$ & $\begin{array}{l}16 \\
18\end{array}$ & $\bar{D}$ & T⿱乛龰己 & $\begin{array}{l}64.5 \\
56 \cdot 4\end{array}$ & $\begin{array}{l}1275 \\
1114\end{array}$ & $\begin{array}{l}21 \cdot 38 \\
23 \cdot 19\end{array}$ & $\begin{array}{r}20 \cdot 65 \\
9 \cdot 30\end{array}$ & $\begin{array}{l}3.88 \\
3 \cdot 17\end{array}$ & $\begin{array}{r}14.3^{8} \\
8 \cdot 15\end{array}$ & $\begin{array}{l}10 \cdot 91 \\
12 \cdot 47\end{array}$ & $\begin{array}{l}4.307 \\
4.308\end{array}$ & $\begin{array}{l}\mathrm{I} \cdot 3 \mathrm{I} \\
\mathrm{I} \cdot 83\end{array}$ & $\begin{array}{l}1 \cdot 829 \\
I \cdot 44 I\end{array}$ \\
\hline $\mathrm{P}_{1}^{2} \times \mathrm{P}_{2}$ & $4 \mathrm{I}$ & $\begin{array}{l}8 \\
\vdots \\
n\end{array}$ & O্口 & $\begin{array}{r}119.8 \\
\text { I } 9.8\end{array}$ & 3229 & $\begin{array}{l}3.9 \\
18.5^{2}\end{array}$ & $5 \cdot 02$ & $\begin{array}{l}\text { I. } \\
\text { I.93 }\end{array}$ & 2.22 & I3.2O & $6 \cdot 086$ & 2.05 & 3.998 \\
\hline $\mathrm{P}_{2}^{2} \times \mathrm{P}_{1}^{2}$ & 7 & ठ & o & 118.7 & $245^{6}$ & I7.57 & I.75 & $2 \cdot 00$ & $2 \cdot 00$ & $12 \cdot 36$ & 3.392 & I 29 & 0.776 \\
\hline$F_{2}$ & 53 & z & Z & $88 \cdot 8$ & I 999 & $20 \cdot 14$ & $12 \cdot 65$ & $2 \cdot 25$ & $3 \cdot 77$ & I I $\cdot 7^{2}$ & 4.457 & I. 66 & $\mathrm{I} \cdot 42 \mathrm{I}$ \\
\hline $\begin{array}{r}\text { I } 95^{8} \\
\mathrm{P}_{\mathbf{1}} \text { p.c.p. }\end{array}$ & 27 & $39 \cdot 15$ & $32 \cdot 3^{6}$ & $67 \cdot 4$ & 2223 & $22 \cdot 33$ & $32 \cdot 46$ & $3 \cdot 70$ & $8 \cdot 22$ & I2.35 & 3.304 & I. I 4 & I 256 \\
\hline $\mathrm{P}_{2}$ p.c.p. & 29 & $39^{\cdot 24}$ & $38 \cdot 4^{8}$ & $156 \cdot 3$ & 7298 & $20 \cdot 16$ & I $4.9 \mathrm{I}$ & $\mathrm{I} \cdot 82$ & I 93 & $\begin{array}{l}(28) \\
17 \cdot 00\end{array}$ & $7 \cdot 426$ & $2 \cdot 50$ & $I \cdot 74 \mathrm{I}$ \\
\hline$F_{2}\left(P_{1} \times P_{2}\right)$ & $5^{\mathrm{I}}$ & $32 \cdot 45$ & $55 \cdot 37$ & & 6063 & $18 \cdot 7^{2}$ & $40 \cdot 5^{8}$ & $3 \cdot 16$ & $9 \cdot 70$ & I 3.55 & 823 & $2 \cdot 35$ & 3.633 \\
\hline$F_{2}\left(P_{2} \times P_{1}\right)$ & 43 & $39^{\cdot 14}$ & $43 \cdot 89$ & $86 \cdot 9$ & 5502 & $22 \cdot 55$ & $31 \cdot 32$ & $3 \cdot 88$ & $9 \cdot 22$ & 15.20 & $9 \cdot 609$ & $2 \cdot 07$ & $2 \cdot 97 \mathrm{r}$ \\
\hline
\end{tabular}

Numbers in brackets represent number of plants scored where this differs from the number given in column two; $\bar{x}=$ mean, $\mathrm{V}=$ variance.

(ii) Structural and meiotic abnormalities. The frequency of cells showing various abnormalities in the parental populations and their hybrids can be seen in table 3. Apart from the asynaptics, the number of abnormal cells is very small in both the parental populations and $\mathrm{F}_{1} \mathrm{~s}$ and is not significantly different when tested by a contingency $\chi^{2}$ using Yates' correction.

\section{(b) External morphological characters}

The means and variances of these characters for the parental populations and their hybrids are set out in table 4. In all cases differences between means were tested using an analysis of variance, and variances were compared by means of the variance ratio test.

(i) Height. This was not scored in the $\mathrm{F}_{1} \mathrm{~s}$.

(ii) Tiller number-The $\mathrm{F}_{1}$ s show a highly significant increase in tiller number over the parental populations in $1957(\mathrm{P}<\mathrm{O} \cdot 00 \mathrm{I})$. That 
is, the $F_{1}$ s show heterosis for tiller number. Differences between the parental populations are negligible.

(iii) Spikelet number. The two parental populations in 1957 do not differ significantly in their means $(\mathrm{P}=0 \cdot 20-0 \cdot \mathrm{Io})$ and the $\mathrm{F}_{1} \mathrm{~s}$ have a significantly lower mean than either parental population $(\mathrm{P}<\mathrm{O} \cdot \mathrm{ooI})$. The $\mathrm{F}_{1} \mathrm{~s}$ therefore show negative heterosis.

In respect of the mean difference between the two spikelets scored on each plant the two parental populations again do not differ significantly from one another in 1957 . The $F_{1}$ s have a significantly lower mean than that of the parental populations ( $\mathrm{P}=\mathrm{O} \cdot \mathrm{OI}-\mathrm{O} \cdot \mathrm{OOI})$.

(iv) Flower number. In 1957 there are significant differences between the two parental populations in respect of the mean number of flowers which they bear $\left(\mathrm{P}=\mathrm{O}^{\circ} \mathrm{05}^{-0} \cdot \mathrm{OI}\right)$. The $\mathrm{F}_{1} \mathrm{~s}$ have a mean flower number similar to that of the $\mathrm{P}_{2}$ parental population.

A significant positive regression was found when the logarithms of the variances for flower number were plotted against the mean $\left(\mathrm{VR}=\mathrm{I} 3.90\right.$ for $\left.\mathrm{N}_{1}=\mathrm{I}, \mathrm{N}_{2}=7 ; \mathrm{P}=0.0 \mathrm{I}-\mathrm{O} \cdot 00 \mathrm{I}\right)$. The residual item is not significant. Thus the variance is solely dependent on the mean and the greater the number of flowers per spikelet the larger the variation between them.

In respect of the variation within plants there are no significant differences between the two types or between them and their hybrids.

\section{(2) The comparison between parental control populations and their $F_{2}$ hybrid derivatives}

In an $\mathrm{F}_{2}$, disturbance of balance may arise from the production of unbalanced gametes as a result of recombination and segregation of the $F_{1}$ genes at gametogenesis (Darlington and Mather, I949). This will be revealed in the $\mathrm{F}_{2}$ by the production of plants which deviate from the mean value of the parental populations. Alternatively, in the case of heterosis occurring in the $F_{1}$, it will be revealed by a deviation from the expected mean of the $F_{2}$ which should lie half-way between that of the $F_{1}$ and the mid-parent value on the basis of additivity and dominance ( $\mathrm{C}$ scaling test: Mather, I949). Should types occur which lie outside the parental range then, even though the mean of the $F_{2}$ does not differ from that of the parents, differences in parental balance will be reflected in an increased variance.

\section{(a) Nuclear characters}

(i) Chiasma frequency. The means and variances of the three $\mathrm{F}_{2} \mathrm{~s}$ and their respective parental populations are given in table $\mathrm{I}$, columns 3 and 4 . Comparisons of the means of the three $\mathrm{F}_{2} \mathrm{~s}$ and the parental populations show that:

(I) The $1957 \mathrm{~F}_{2}$ does not differ significantly from the $\mathrm{P}_{1}$ parental populations but does differ significantly from the $\mathrm{P}_{2}$ parental populations ( $\mathrm{P}=0 \cdot 05-\mathrm{O} \cdot \mathrm{OI})$. 
(2) The $1958\left(\mathrm{P}_{1} \times \mathrm{P}_{2}\right) \quad \mathrm{F}_{2}$ does not differ significantly from the $\mathrm{P}_{1}$ parental populations but differs significantly from the $\mathrm{P}_{2}$ parental populations $\left(\mathrm{P}=0 \cdot 05^{-0} \cdot 0 \mathrm{I}\right)$.

(3) The r958 $\left(\mathrm{P}_{2} \times \mathrm{P}_{1}\right) \mathrm{F}_{2}$ differs significantly from both the $\mathrm{P}_{\mathbf{1}}$ and $\mathrm{P}_{2}$ parental populations $(\mathrm{P}=\mathrm{0} \cdot \mathrm{Or}-\mathrm{O} \cdot 0 \mathrm{OI}$ and $\mathrm{P}<\mathrm{O} \cdot 00 \mathrm{I}$ respectively).

The low chiasma frequency of the $195^{8}\left(\mathrm{P}_{2} \times \mathrm{P}_{1}\right) \mathrm{F}_{2}$ is the result of a significant increase in the frequency of asynaptic cells in this population when compared with the parental populations grown in that year $(\mathrm{P}<0.00 \mathrm{I}$; table 3$)$. This increase is reflected in two ways:

(I) An increase in the number of cells carrying one pair of univalents.

(2) The presence of cells carrying more than one pair of univalents (plate II, fig. 4).

The frequency of cells showing asynapsis in the $195^{8}\left(\mathrm{P}_{1} \times \mathrm{P}_{2}\right) \mathrm{F}_{2}$ is also significantly higher than in the parental populations grown in the same year $(\mathrm{P}<\mathrm{O} \cdot \mathrm{oor})$. In this case the same pattern of asynapsis is evident as that described for the $195^{8}\left(\mathrm{P}_{2} \times \mathrm{P}_{1}\right) \mathrm{F}_{2}$, although here it is less extreme (table 5). The frequency of asynaptic cells in the ${ }_{1957} \mathrm{~F}_{2}$ is not significantly different from that of its parents, and no cell was seen with more than two pairs of univalents.

The mean variation in chiasma frequency between the pollen mother cells of a parental plant and the $\mathrm{F}_{2} \mathrm{~s}$ does not differ significantly in either year. The variation between bivalents within a cell is, however, significantly greater in the $195^{8}\left(\mathrm{P}_{2} \times \mathrm{P}_{\mathbf{1}}\right) \mathrm{F}_{2}$ than in the parental populations $\left(\mathrm{P}=\mathrm{O}^{\circ} \mathrm{05}-\mathrm{O} \cdot 0 \mathrm{I}\right)$, although the other two $\mathrm{F}_{2}$ populations are not significantly more variable than the parents.

(ii) Structural and meiotic abnormalities. The frequency of cells showing structural and meiotic abnormalities is given in table 3 . The parental populations and $\mathrm{F}_{2} \mathrm{~S}$ were tested for differences by means of a contingency $\chi^{2}$ with Yates' correction. Apart from the case of asynapsis, which has already been considered, it was found that neither of the $\mathrm{F}_{2} \mathrm{~s}$ differ significantly from the parental populations.

One of the $\left(\mathrm{P}_{2} \times \mathrm{P}_{1}\right) \mathrm{F}_{2}$ plants in $195^{8}\left(\mathrm{~B}_{5} 8^{1}\right)$ is interesting in that it showed a breakdown of the meiotic cycle. The cycle proceeded normally until AI of meiosis (plate II, fig. 5). Then, instead of being followed by a normal second division, breakdown of the AI spindle was followed by the immediate formation of another single spindle at right angles to the original one. The $\mathrm{I} 4$ half bivalents resulting from the AI stage of division therefore all arranged themselves at the equator of this second spindle (plate II, fig. 6), whereupon they divided mitotically (plate II, figs. 7 and 8 ). Preparations were made from several flowers of the tiller and the result was the same in every case. 


\section{(b) External morphological characters}

The means and variances for these characters are given in table 4 . As in section 3 (I) the means were compared by analyses of variance and the variances by variance ratios unless stated otherwise.

(i) Height. The two parental populations do not differ significantly from one another in their mean height. The height of the $\left(\mathrm{P}_{1} \times \mathrm{P}_{2}\right)$ $\mathrm{F}_{2}$ differs significantly from these two parental populations $(\mathrm{P}<\mathrm{O} \cdot 00 \mathrm{I})$.

(ii) Tiller number. The $\mathrm{F}_{1}$ s show positive heterosis for this character in 1957. The expected value of the $\mathrm{F}_{2}$ mean is therefore $90^{\circ} \mathrm{0} \pm 5^{\circ} \mathrm{O}$, and neither of the $\mathrm{F}_{2} \mathrm{~s}$ deviate significantly from this.

\section{TABLE 5}

Frequency of cells with $0-7$ pairs of univalents. In all cases 20 cells per plant were analysed

\begin{tabular}{|c|c|c|c|c|c|c|c|c|c|c|}
\hline \multirow{2}{*}{ Item } & & & \multicolumn{8}{|c|}{ No. of cells having $0-7$ pairs of univalents } \\
\hline & & & o & I & 2 & 3 & 4 & 5 & 6 & 7 \\
\hline D $\quad 1957$ & & & & & & & & & & \\
\hline$P_{1}$ p.c.p. & . & . & 266 & 14 & $\ldots$ & $\ldots$ & $\ldots$ & $\ldots$ & $\ldots$ & $\ldots$ \\
\hline $\mathrm{P}_{2}$ p.c.p. & . & . & 332 & 8 & $\cdots$ & ... & $\cdots$ & $\cdots$ & $\cdots$ & $\cdots$ \\
\hline $\begin{array}{l}\mathbf{P}_{1} \times \mathbf{P}_{2} \\
\mathbf{P}_{2} \times \mathbf{P}_{1}\end{array}$ & . & $\cdot$ & 606 & ${ }^{14}$ & $\cdots$ & $\cdots$ & $\cdots$ & $\cdots$ & $\cdots$ & $\cdots$ \\
\hline & & . & 554 & 24 & 2 & $\ldots$ & $\ldots$ & $\cdots$ & ... & $\ldots$ \\
\hline $195^{8}$ & & & & & & & & & & \\
\hline $\mathrm{P}_{1}$ p.c.p. & · & . & 193 & 7 & $\cdots$ & $\cdots$ & $\cdots$ & $\cdots$ & $\cdots$ & $\cdots$ \\
\hline $\mathrm{P}_{2} \stackrel{\mathrm{p} \cdot \mathrm{C} \cdot \mathrm{P} \cdot}{\left.\mathrm{P}_{1} \times \mathrm{P}_{2}\right)}$ & : & . & $\begin{array}{l}199 \\
367\end{array}$ & $\begin{array}{l}1 \\
25\end{array}$ & $\begin{array}{c}\cdots \\
5\end{array}$ & $\ddot{2}$ & $\dddot{\mathrm{I}}$ & $\ldots$ & $\cdots$ & $\ldots$ \\
\hline $\mathrm{F}_{2}\left(\mathrm{P}_{2}^{*} \times \mathrm{P}\right.$ & & . & $29 \mathrm{I}$ & 60 & 22 & 16 & 6 & 2 & 2 & I \\
\hline
\end{tabular}

(iii) Spikelet number. Since the $\mathrm{F}_{1} \mathrm{~s}$ show negative heterosis in respect of this character then, from the 1957 data, the expected mean of the $\mathrm{F}_{2} \mathrm{~s}$ is $20.34 \pm 0.37$. Using $t$ tests it was found that the I957 $\mathrm{F}_{2}$ does not deviate significantly from this value $(P=0 \cdot 70-0 \cdot 60)$. The I958 $\left(\mathrm{P}_{1} \times \mathrm{P}_{2}\right) \quad \mathrm{F}_{2}$ also does not deviate significantly from the expected value $(\mathrm{P}=0.10-0.05)$. The I958 $\left(\mathrm{P}_{2} \times \mathrm{P}_{1}\right) \quad \mathrm{F}_{2}$ however gives a value for $t$ of $2 \cdot 7 \mathrm{I}$ for $\mathrm{N}=\mathrm{I} 25$ which has a probability of o.OI-O.OOI.

In respect of the variation in spikelet number within plants it was again necessary to determine the expected mean value of the $\mathrm{F}_{2} \mathrm{~s}$. This was found to be $2 \cdot 73 \pm 0.3 \mathrm{I}$. On the evidence of $t$ tests, only the I $958^{8}\left(\mathrm{P}_{2} \times \mathrm{P}_{1}\right) \mathrm{F}_{2}$ differs significantly from this $(t=3.06$ for $\mathrm{N}=\mathrm{I} 25 ; \mathrm{P}=0 . \mathrm{OI}-\mathrm{O} \cdot 00 \mathrm{I}$ ).

(iv) Flower number. The means of the $\mathrm{F}_{2} \mathrm{~s}$ in both years fall between those of the parental populations. In 1957 this difference is not significant $(\mathrm{P}=0 \cdot 20-\mathrm{O} \cdot \mathrm{IO})$ whereas in $195^{8}$ both $\mathrm{F}_{2}$ s differ significantly 
from both parental populations. The variances are dependent only on the means and so provide no additional information.

The variation in the number of flowers per spikelet within each plasit does not differ significantly between any of the $\mathrm{F}_{2} \mathrm{~s}$ and the parental populations in either year.

\section{DISCUSSION}

(1) The relationship between Lolium perenne and L. italicum

The results of the crosses described in the previous section are summarised in table 6 .

TABLE 6

Occurrence of disturbed (solid block) and undisturbed (plain block) balance in the $F_{1} s$ and $\mathrm{F}_{2} \mathrm{~s}$ of crosses between Lolium perenne and L. italicum.

\begin{tabular}{|c|c|c|c|c|}
\hline Character & $F_{1}$ & $1957 F_{2}$ & $\left(P_{1} \times P_{2}\right) F_{2} 1958$ & $\left(P_{2} \times P_{1}\right) F_{2} 1958$ \\
\hline \multicolumn{5}{|l|}{ Chiasma frequency } \\
\hline \multicolumn{5}{|l|}{ Cell variance } \\
\hline \multicolumn{5}{|l|}{ Bivalent variance } \\
\hline \multicolumn{5}{|l|}{$\begin{array}{c}\text { Structural \& meiotic } \\
\text { abnormalities }\end{array}$} \\
\hline Height & \multicolumn{2}{|c|}{ Not scored } & & \\
\hline \multicolumn{5}{|l|}{ Tiller number } \\
\hline Spikelets $\left\{\frac{\text { mean }}{\text { difference }}\right.$ & & & & \\
\hline Flowers $\left\{\begin{array}{l}\text { mean } \\
\text { difference }\end{array}\right.$ & & & & \\
\hline
\end{tabular}

From the chromosomal point of view the two species appear to be structurally alike. In none of the hybrid plants scored are there any signs of heteromorphic bivalents or other indications of structural differences. The mean chiasma frequency of the $F_{1}$ hybrids is as high as that of the $P_{1}$ parental population. Thus there is no evidence of reduction in effective pairing in the first generation when the two parental populations are crossed. There is also no increase in either the frequency of cells showing unpaired chromosomes or in the frequency of meiotic irregularities.

Similarly when considering flower number there is no evidence that the $F_{1}$ hybrids are less well balanced than the two parental populations. Even though the two parental populations have become differently adapted in some respects, for example they differ in mean 
chiasma frequency and flower number, nevertheless they are able to interbreed without causing any major upsets in the $F_{1}$ in regard to these characters.

This is not true of all the characters however. In respect of tiller number and mean spikelet number the $F_{1}$ s have a mean phenotype which differs from that of the two parental populations. While the characters scored are subject to environmental influences it is considered unlikely, under the conditions in which the plants were grown in any one year, that these would produce such a major effect.

From table 6 it appears that the $F_{2}$ populations differ in the extent to which disturbance of balance occurs. In 1957 the $F_{2}$ shows no sign of disturbance for any of the characters scored, while in $195^{8}$ the $\left(\mathrm{P}_{2} \times \mathrm{P}_{1}\right) \mathrm{F}_{2}$ has many characters disturbed.

The drastic effects sometimes produced by crossing the two parental populations are revealed most clearly in the case of chiasma frequency. The $195^{8}\left(\mathrm{P}_{2} \times \mathrm{P}_{1}\right) \mathrm{F}_{2}$ population has an extremely low mean chiasma frequency (see table $\mathrm{I}$ ) with a consequently high variation between plants. Some of the types which have arisen by segregation have therefore not been able to achieve the maximum number of chiasmata possible. Hence there will be an increase in the variation between plants and a consequently lower mean chiasma frequency. Although the mean chiasma frequency of the $195^{8}\left(\mathrm{P}_{2} \times \mathrm{P}_{1}\right) \mathrm{F}_{2}$ is significantly lower than that of both parental populations there is still an average of more than one chiasma per bivalent so that this in itself need not necessarily lead to univalent formation. The distribution of these chiasmata, however, is not uniform either between or within plants, some having very low chiasma frequencies with a high proportion of univalents. Such plants are likely to have produced unbalanced pollen grains which would therefore lead to a reduction in their fertility. Spontaneous asynapsis is an uncommon phenomenon, although exceptional instances are known, for example in Locusta migratoria (Rees, 1957) and in Schistocerca gregaria (John and Naylor, in preparation). Presumably the highly asynaptic individuals in the $\mathrm{F}_{2}$ populations have arisen as a consequence of recombination and segregation in the $F_{1}$.

In respect of mean spikelet number, mean flower number and height, segregation again results in some $\mathrm{F}_{2}$ types which show disrupted balance.

A consideration of the developmental stability of the hybrids and their derivatives also shows similar results. Any variation between structures which are genetically identical must be environmentally induced and hence will be a measure of the stability or homeostasis of that individual (Mather, 1953; Lerner, 1954). Thus the variation in chiasma frequency between the cells of an individual, and between bivalents within a cell, may both be regarded as measures of stability. The same must also be true, though to a lesser extent, of the differences in spikelet number between the two tillers scored in each plant, 
and of the differences in flower number between the two spikelets. In the case of variation in chiasma frequency between cells within a plant, and in the case of variation in flower number within plants, there are no significant differences between the parental populations and either the $F_{1}$ hybrids or the $F_{2}$ hybrid derivatives. Since stability in development is a reflection of the genic balance produced by selection (Jinks and Mather, 1955) then such results indicate that the two parental populations can hybridise without resulting in a disruption of balance. In respect of variation between the bivalents of a cell the $195^{8}\left(\mathrm{P}_{2} \times \mathrm{P}_{1}\right) \mathrm{F}_{2}$ is significantly less stable than the parental populations. Thus for this character there is evidence that the two parental populations have become differentiated in respect of the polygenic systems controlling it.

The differences in spikelet number between the two tillers scored for each plant show that the hybrids between the two parental populations tend to be more stable than the parental populations themselves. If we assume that the level of variation shown by the parents is actively maintained by selection pressure then the greater stability of the hybrids can be regarded as a departure from the parental optimum and a sign of loss of adaptation. On the other hand it may be comparable to the situation described by Paxman (1956) in Nicotiana rustica where variation in the lengths of stamens and pistils in flowers, together with the leaf shape index, was associated with their position on the plant.

Although the two forms $L$. perenne and $L$. italicum can interbreed without difficulty such intercrossing may lead to a loss of fitness in the hybrids and hybrid derivatives. The two forms must therefore consist of independently balanced polygenic systems which for some characters, such as tiller number, have become so differentiated as to result in a disruption of balance when the two forms are crossed. For other characters the genic combinations of the two forms do not appear to have lost their relational balance and no major upsets occur in the $F_{1}$ hybrids. Segregation and recombination of their parts, however, may result in unbalanced gametes and a consequent decrease in fitness of the $\mathrm{F}_{2}$ plants.

The ease with which the two forms can interbreed and the complete absence of differences in chromosome organisation is an indication that the two types may not have become separated until fairly recent times. Despite the fact that they overlap in their geographical distribution they can be distinguished morphologically. But they cannot be consistently distinguished in genetical terms; therefore, like the morphologically distinct races of Achillea borealis (Clausen, 1951), they are not fundamentally distinct species. Indeed, intermediate forms have been reported in the wild (Armstrong, 1937; Hubbard, 1954). There is a breakdown of many of the characters scored in certain of the $F_{2}$ hybrids and this must lead on occasions to the production of unbalanced gametes. But this is not true of all the 
characters. This breakdown therefore is insufficient to establish an effective internal isolation between the two genotypes.

The findings of breeding analysis on these two supposedly distinct species justifies a general consideration of the breeding affinities within the genus.

\section{(2) Species relationships within the genus Lolium}

The only available data relating to the general problem of speciation in the genus Lolium are the experimental results of Jenkin (I93 I, I 935, I939, I $\left.945 a, b, c, d, \mathrm{I} 955^{a}, b\right)$. This information is summarised in tables 7 and 8 .

As Jenkin himself points out there is a clear tendency for the highest seed-set and germination to occur in crosses between the self-pollinating types and between the cross-pollinating types respectively. When crosses are made between self-pollinating and crosspollinating types the results obtained depend upon the choice of parent. When L. rigidum is used as either staminate or pistillate parent the percentage germination is invariably very low, even though there may be an appreciable seed-set. A similar result follows provided the self-pollinating types are used as pistillate parents. In all cases where self-pollinating types are used as staminate parents the percentage germination is considerably higher, while the seed-set varies. It is apparent therefore that within the genus Lolium the self-pollinating and cross-pollinating types form two distinct groups between which at least partial barriers to crossing exist.

Jenkin ( 1954, 1955) has used backcrosses and $\mathrm{F}_{2} \mathrm{~s}$ to determine the fertility of the $F_{1}$ hybrids. His conclusions are summarised in table 8 . From a consideration of tables 7 and 8 it is possible to make the following generalisations:

(a) In crosses between the self-pollinating types few data are available. Two of the three hybrids examined were however found to be female sterile. The female fertile hybrid was male sterile. Hybrids between self-pollinating types are therefore incapable of maintaining themselves beyond the $\mathrm{F}_{1}$ generation. Such types must then be reproductively isolated and may be justifiably regarded as distinct species.

(b) Hybrids between $L$. loliaceum and both $L$. remotum and $L$. temulentum develop abnormally although the two latter species when intercrossed produce normal offspring. L. remotum and $L$. temulentum thus appear to be more closely related to each other than to $L$. loliaceum.

(c) All the crosses between members of the outbreeding group result in fully fertile $\mathrm{F}_{1} \mathrm{~s}$. $\mathrm{F}_{2} \mathrm{~s}$ between the various $\mathrm{F}_{1} \mathrm{~s}$ are also fully fertile. Since the different members of this group are able to interbreed freely to produce fertile hybrids and hybrid derivatives they cannot be reproductively isolated. There seems to be no justification therefore for considering each of these types to be separate species. It seems 
TABLE 7

Percentage seed-set and germination in crosses involving different Lolium types

\begin{tabular}{|c|c|c|c|c|c|c|c|c|c|c|c|c|}
\hline & \multicolumn{6}{|c|}{ Self-pollinating } & \multicolumn{6}{|c|}{ Cross-pollinating } \\
\hline & \multicolumn{2}{|c|}{ L. remotum } & \multicolumn{2}{|c|}{ L. temulentum } & \multicolumn{2}{|c|}{ L. loliaceum } & \multicolumn{2}{|c|}{ L. perenne } & \multicolumn{2}{|c|}{ L. italicum } & \multicolumn{2}{|c|}{ L. rigidum } \\
\hline & SS & G & SS & $\mathrm{G}$ & SS & G & SS & $\mathrm{G}$ & SS & G & SS & G \\
\hline $\begin{array}{l}\text { Self-pollinating } \\
\text { L. remotum } \\
\text { L. temulentum } \\
\text { L. loliaceum }\end{array}$ & $\begin{array}{l}5^{8} \\
\text { I6 }\end{array}$ & $\begin{array}{c}91 \\
\text { IOO* }\end{array}$ & ${ }_{78}{ }^{\circ}$. & $\begin{array}{l}95 \\
87 *\end{array}$ & $\begin{array}{c}\mathrm{N} \\
57\end{array}$ & data & $\begin{array}{l}65 \\
77 \\
50\end{array}$ & $\begin{array}{r}4 \\
1 \\
25\end{array}$ & $\begin{array}{l}69 \\
43 \\
\text { I } 8\end{array}$ & $\begin{array}{c}0 \\
0 \\
\text { self? } \\
\text { I }\end{array}$ & $\begin{array}{l}43 \\
79 \\
44\end{array}$ & $\begin{array}{c}0 \\
4 \\
3^{x} \\
\text { I seed }\end{array}$ \\
\hline $\begin{array}{l}\text { Cross-pollinating } \\
\text { L. perenne . } \\
\text { L. italicum . } \\
\text { L. rigidum . }\end{array}$ & $\begin{array}{l}23 \\
43 \\
55\end{array}$ & $\begin{array}{r}34 \\
38 \\
0\end{array}$ & $\begin{array}{l}70 \\
25 \\
39\end{array}$ & $\begin{array}{r}79 \\
34 \\
<2\end{array}$ & $\begin{array}{l}27 \\
60 \\
79\end{array}$ & $\begin{array}{c}98 \\
93 \\
\text { I seed }\end{array}$ & $\begin{array}{l}79 \\
64\end{array}$ & $\begin{array}{l}99 \\
66\end{array}$ & $\begin{array}{l}75 \\
60\end{array}$ & $\begin{array}{l}78 \\
87\end{array}$ & $\begin{array}{l}55 \\
63\end{array}$ & $\begin{array}{l}46 \\
88\end{array}$ \\
\hline
\end{tabular}

* = abnormal development. SS = seed-set. $\mathrm{G}=$ germination. Data after Jenkin, I93 I-I 955.

TABLE 8

Fertility of the $F_{1}$ plants. Data after Jenkin, 1954, 1955

\begin{tabular}{|c|c|c|c|c|c|c|c|}
\hline \multirow[b]{2}{*}{ 우 } & & \multicolumn{3}{|c|}{ Self-pollinating } & \multicolumn{3}{|c|}{ Cross-pollinating } \\
\hline & & $\underset{\text { remotum }}{L .}$ & $\begin{array}{c}L . \\
\text { temulentum }\end{array}$ & $\begin{array}{c}L . \\
\text { loliaceum }\end{array}$ & $\begin{array}{c}L . \\
\text { perenne }\end{array}$ & $\stackrel{\text { L. }}{\text { italicum }}$ & $\underset{\text { rigidum }}{L .}$ \\
\hline $\begin{array}{l}\text { Self-pollinating } \\
\text { L. remotum }\end{array}$ & . & $\ldots$ & $\begin{array}{l}\text { of fertile } \\
\text { o sterile }\end{array}$ & No $F_{1}$ & No data & No $F_{1}$ & No $F_{1}$ \\
\hline L. temulentum & . & No data & $\ldots$ & No data & No data & No $F_{1}$ & No data \\
\hline L. loliaceum & . & $\begin{array}{l}q \text { sterile } \\
\text { đa no data }\end{array}$ & $\begin{array}{c}\text { Low } \\
\text { o fertility } \\
\text { o no data }\end{array}$ & $\ldots$ & $\begin{array}{c}\text { Low } \\
\text { q fertility } \\
\text { of sterile }\end{array}$ & No data & $\begin{array}{l}\text { o f fertile } \\
\text { ot sterile }\end{array}$ \\
\hline $\begin{array}{l}\text { Cross-pollinatin } \\
\text { L. perenne }\end{array}$ & . & $\begin{array}{c}\text { Low } \\
\text { of fertility } \\
\text { đ' sterile }\end{array}$ & $\begin{array}{c}\text { Low } \\
\text { of fertility } \\
\text { đ sterile }\end{array}$ & $\begin{array}{l}\text { o No data } \\
\text { ô sterile }\end{array}$ & ... & $\begin{array}{l}\text { o f fertile } \\
\text { ot fertile }\end{array}$ & $\begin{array}{l}\text { of fertile } \\
\text { of fertile }\end{array}$ \\
\hline L. italicum & . & $\begin{array}{l}\text { q sterile } \\
\text { đo sterile }\end{array}$ & $\begin{array}{l}\text { Low } \\
\text { o fertility } \\
\text { s sterile }\end{array}$ & $\begin{array}{l}\text { o sterile } \\
\text { o }^{*} \text { sterile }\end{array}$ & $\begin{array}{l}q \text { fertile } \\
\delta^{*} \text { fertile }\end{array}$ & $\ldots$ & $\begin{array}{l}\text { of fertile } \\
\text { ot fertile }\end{array}$ \\
\hline L. rigidum & . & No $F_{1}$ & $\begin{array}{l}\text { of fertile } \\
\text { o sterile }\end{array}$ & No data & $\begin{array}{l}\text { of fertile } \\
\text { of fertile }\end{array}$ & $\begin{array}{l}\text { Of fertile } \\
\text { of fertile }\end{array}$ & $\ldots$ \\
\hline
\end{tabular}


preferable to regard these forms as subspecies, particularly since they overlap in at least a part of the range of their geographical distribution.

Finally there is the question of the relation between the in- and outbreeding groups. All the available evidence supports the contention that in evolution inbreeding types invariably evolve from outbreeders (Darlington and Mather, I949). There seems no good reason to doubt the applicability of this conclusion in the genus Lolium (contra Jenkin, I955b). Indeed the finding (Naylor and Rees, I958) that in L. temulentum duplication of parts of chromosomes has occurred relative to L. perenne, can be used in support of the secondary origin of the inbreeding types (Lewis and John, I959).

\section{SUMMARY}

I. Crosses have been made between $L$. perenne and L. italicum, and the $F_{1}$ hybrids and $F_{2}$ hybrid derivatives compared with the two forms in respect of four nuclear and six external morphological characters.

2. The $F_{1}$ s show disturbance of balance in three morphological characters only. In the $\mathrm{F}_{2}$ the results are variable both within and between years, and the amount of disturbance may be greater than or less than that observed in the $\mathrm{F}_{1}$.

3. The disturbances found in both hybrid generations are, however, insufficient to establish an effective internal isolation between $L$. perenne and L. italicum. From this point of view, therefore, they cannot be regarded as distinct species.

4. This is also borne out by a re-analysis of the data of Jenkin which permits an extension of this conclusion to the third openpollinating form L. rigidum too. These three forms are probably best regarded as subspecies.

5. Contrariwise the three self-pollinating types, $L$. remotum, $L$. temulentum and $L$. loliaceum, may be justifiably regarded as distinct species.

Acknowledgments.-I am grateful to Dr H. Rees for suggesting this work and for supervision during its progress, and to Professor K. Mather, F.R.s. and to Dr B. John for helpful criticism in the preparation of the manuscript.

\section{REFERENCES}

ARmstrong, S. F. 1937. British Grasses and their Employment in Agriculture. Cambridge University Press.

Clausen, J. I95I. Stages in the Evolution of Plant Species. New York: Cornell University Press.

Darlington, C. D., AND mather, K. 1949. The Elements of Genetics. Allen and Unwin, London.

HUBbaRD, C. E. 1954. Grasses. Pelican Books, London.

JENKIN, T. J. I 93 I. The interfertility of Lolium perenne and $L$. perenne var. multiflorum. Bull. Welsh Pl. Breed. Sta., H, I2, I 2 I-I 25. 


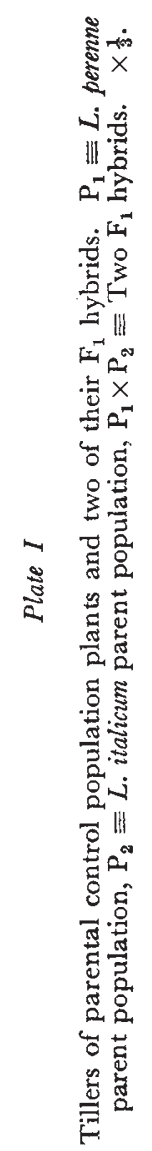




$$
\rightarrow
$$




\section{Plate II}

All photomicrographs $\times 175^{\circ}$.

Fig. I.- $1958 \mathrm{P}_{1}$ plant-normal first metaphase.

FIG. 2.- I $958 \mathrm{P}_{2}$ plant-normal first metaphase.

FIG. 3.- $195^{8}\left(\mathrm{P}_{2} \times \mathrm{P}_{1}\right) \mathrm{F}_{2}$ plant-normal first metaphase, 7 II.

FIG. 4.- $195^{8}\left(\mathrm{P}_{2} \times \mathrm{P}_{1}\right) \mathrm{F}_{2}$ plant showing asynapsis, $4 \mathrm{II}+6 \mathrm{I}$. Cell with only 4 chiasmata.

FIG. 5.- $1958\left(\mathrm{P}_{2} \times \mathrm{P}_{1}\right) \mathrm{F}_{2}$ plant $\mathrm{B}_{5} 8^{1}$. Normal first anaphase.

FIG. 6.-1958 $\left(\mathrm{P}_{2} \times \mathrm{P}_{1}\right) \mathrm{F}_{2}$ plant $\mathrm{B}_{5} 8^{1}$. Abnormal second meiotic division. Diploid no. of half bivalents arranged on equator.

Fig. 7.- $195^{8}\left(\mathrm{P}_{\mathbf{2}} \times \mathrm{P}_{\mathbf{1}}\right) \mathrm{F}_{\mathbf{2}}$ plant $\mathrm{B}_{5} \mathbf{8}^{1}$. Abnormal second meiotic division. Half bivalents dividing mitotically.

FIG. 8.- $195^{8}\left(\mathrm{P}_{2} \times \mathrm{P}_{1}\right) \mathrm{F}_{2}$ plant $\mathrm{B}_{5} 8^{1}$. Abnormal second meiotic division. Divided half bivalents moving towards the poles. 


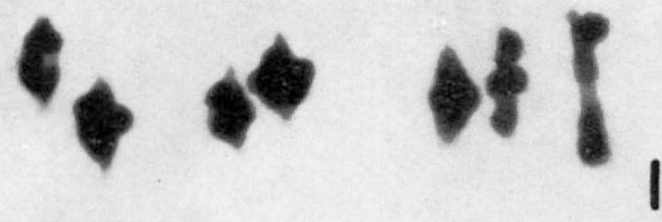

- $1880^{\circ}$

2

$v^{4}$

3

if ide

4

$-1$

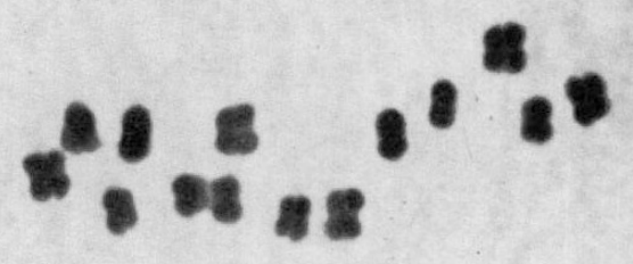

-

is

c

5

6

$\bullet$

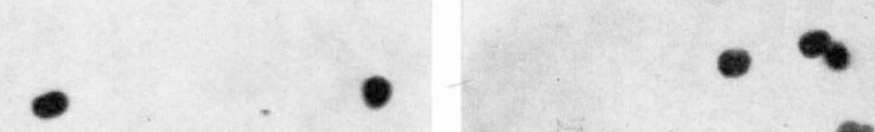

-

\section{농}

$188^{8} 8$.

เ - 6 $\bullet$

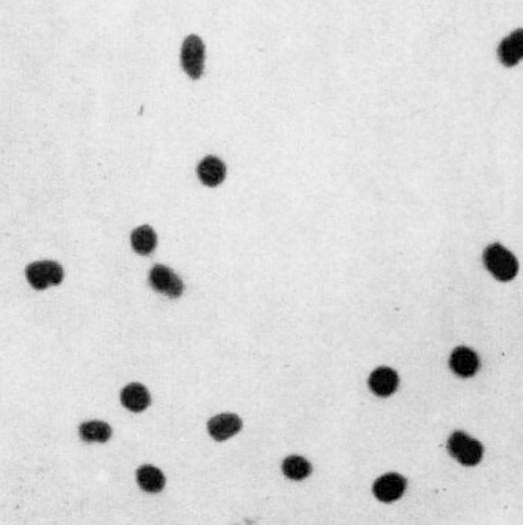

7

8 
JENKIN, T. J. 1935. Interspecific and intergeneric hybrids in herbage grasses. II. Lolium perenne $\times$ L. temulentum. F. Genet., 3I, 379-4I I.

JENKIN, T. J. 1954a. Interspecific and intergeneric hybrids in herbage grasses. V. Lolium rigidum sens. ampl. with other Lolium species. F. Genet., 52, 252-28r.

JENKIN, T. J. 1954b. Interspecific and intergeneric hybrids in herbage grasses. VI. Lolium italicum A.Br. intercrossed with other Lolium types. 7. Genet., 52, 282-299.

JENKIN, T. J. 1954c. Interspecific and intergeneric hybrids in herbage grasses. VII. Lolium perenne L. with other Lolium species. 7. Genet., 52, 300-3r 7 .

JENKIN, T. J. 1954d. Interspecific and intergeneric hybrids in herbage grasses. VIII. Lolium loliaceum, Lolium remotum and Lolium temulentum, with references to "Lolium canadense". 7. Genet., 52, 318-331.

JENKIN, T. J. 1955a. Interspecific and intergeneric hybrids in herbage grasses. XVII. Further crosses involving L. perenne. .7. Genet., 53, 442-466.

JENKIN, T. J. 1955b. Interspecific and intergeneric hybrids in herbage grasses. XVIII. Various crosses including Lolium rigidum sens. ampl. with L. temulentum and L. loliaceum with Festuca pratensis and with $F$. arundinacea. F. Genst., 53, $467-486$.

JENKIN, T. J., AND THOMAS, P. T. 1939. Interspecific and intergeneric hybrids in herbage grasses. III. Lolinm loliaceum and Lolium rigidum. 3. Genet., 37, 255-286.

JINKS, J. L., AND MATHER, K. i955. Stability in development of heterozygotes and homozygotes. P.R.S., B, $143,56 \mathrm{r}-578$.

JOHN, B., AND NAYLOR, B. In preparation. Anomalous chromosome behaviour in the germ line of Schistocerca gregaria.

LEWIS, K. R., AND JOHN, B. 1959. Breakdown and restoration of chromosome stability following inbrceding in a locust. Chromosoma, ro, 539-618.

Lerner, I. M. 1954. Genetic Homeostasis. Oliver and Boyd, Edinburgh.

MAtheR, к. 1911. Variation and selection of polygenic characters. F. Genet., $4 I$, I 59 - 193 .

mather, K. 1943. Polygenic inheritance and natural selection. Biol. rev., I8, $32-64$.

Mather, K. 1949. Biometrical Genetics. Methuen, London.

MATHER, к. 1953. Genetical control of stability in development. Heredity, 7, $297-33^{6}$.

NAYlOR, B., AND REES, H. 1958. Chromosome size in Lolium temulentum and L. perenne. Nature, $181,854-855$.

PAXman, G. J. 1956. Differentiation and stability in the development of Nicotiana rustica. An. Bot., 22, 331-347.

REES, ז. 1957. Distribution of chiasinata in an "asynaptic" locust. Nature, 180,559 . 